\title{
Grand Teton National Park BreEding Bird Monitoring ProjeCt
}

\author{
MARTIN. L. CODY \\ DEPARTMENT OF ORGANISMIC BIOLOGY \\ ECOLOGY AND EVOLUTION \\ UNIVERSITY OF CALIFORNIA $\uparrow$ LOS ANGELES
}

\section{$\downarrow$ OVERVIEW: GTNP BREEDING BIRD MONITORING PROJECT}

1. Following initial independent work by M. L. Cody and $3 y$ funding from NPS, we instigated a scheme for long-term monitoring of breeding land bird populations in a wide variety of habitats representative of the northern Rockies and the Greater Yellowstone Ecosystem (GYE). Census sites are located almost entirely within Grand Teton National Park, where a broad range of representative vegetation types is accessible within close geographic proximity.

2. 30 monitoring sites are established within and adjacent to the park in pristine habitat. Sites range from the Jackson Hole lowlands to subalpine and alpine sites, from meadow, sagebrush and marshland, through willow scrub, cottonwood and aspen woodlands, to lodgepole pine and spruce-fir forests. Some sites have a monitoring history of $>30 \mathrm{y}$; others were established in the mid-1990's.

3. The location and accessibility of the study sites permits all to be regularly and repeatedly censused during the short (6-week) breeding season. Census sites are standardized in area (5-10 ha in size) and mapped in detail (topographic features, vegetation). Census scheduil's, timing, and methodological protocols are established, and allow for controlled inter-site and inter-year comparisons in breeding bird populations, species composition, and densities.

\section{SEASON: COVERAGE AND PARTICIPANTS}

Participants. Six persons participated in the 2000 census effort, as listed below.

Martin L. Cody

Dept. Organismic Biology, Ecology \& Evolution

University of California

Los Angeles, CA 90095-1606

PH: 310-825-1327; FX: 310-206-3987;

EM: mlcody@ucla.edu

\section{J. Grimes}

5445 Tulane Ave.,

Toledo, OH 43611

419-726-4443;

EM: cjgrimes@hotmail.com

Mary Ann Harlow

UW-NPS Research Station

PO Box 3166

Laramie, WY 82071-3166

EM: MHarlow@uwyo.edu

Matt Killebrew

P.O. Box 284

Moose, WY 83012

PH: 307/734/0652;

EM: Matt_Killebrew@nps.gov 
Susan Patla

Wyoming Game and Fish Dept,

PO Box 67,

Jackson, WY 83001

EM: spatla@state.wy.us

Sue Wolff

PO Box 91

Moose, WY 83102

307-739-3464; EM: susan_wolff@nps.gov

\section{Site Coverage.}

Nineteen of the 30 monitoring sites were assessed in 2000. Coverage was continued on those sites with the longest monitoring history, which in some cases covers several decades; coverage also spanned the full habitat range of GTNP's monitoring sites (see Table 1.).

Table 1. Coverage of GTNP Breeding Bird Bird Monitoring Sites 1966-2000.

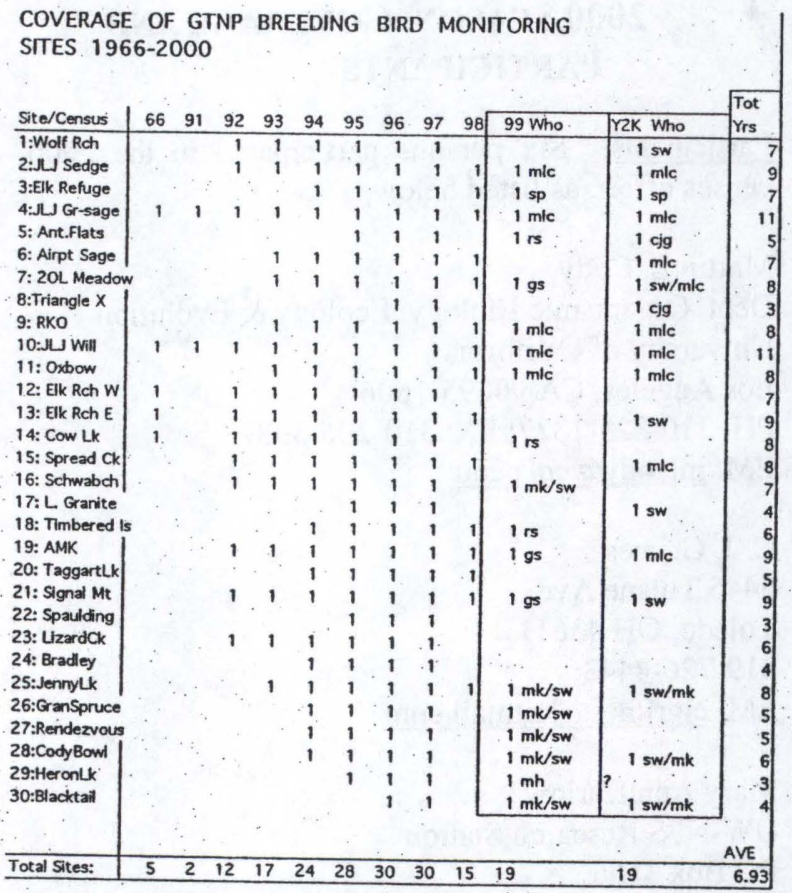

The last column of the above table indicates the sites censuses during the 2000 season; the selection continues an unbroken continuity at important "flagship" sites and also extends coverage of some less routinely censused areas. Overall, the 30 sites have been censused over seven calendar years.
The list of breeding species at the monitoring sites (Appendix A) was extended to 151, with the inclusion of Northern Oriole at Site 11: Oxbow Willow-Aspen.

Y2000 was a dry year, with wetlands especially showing this effect. A review of the climate data from the Moran weather station is given in Figure 1. Over the last $40 \mathrm{y}$, precipitation AUGJUL (basically the 12 months preceding a breeding census survey) averaged $633 \mathrm{~mm}$. Precipitation 1999-2000 was slightly below average $(607 \mathrm{~mm})$, and annual temperature somewhat above average $\left(2.72^{\circ} \mathrm{C}\right.$, cf. average $\left.2.47^{\circ} \mathrm{C}\right)$.

Breeding densities of representative common species are summarized in sites grouped into "meadow" (Figure 2a), "willow-aspencottonwood" (Figure 2b) and "pine-spruce-fir" Figure 2c) sites respectively. Densities at most sites were much like those of previous years, although densities in two forest sites (\#s 21,25) appeared to be sharply reduced.

Analyses of seven sparrow species (fam. Emberizidae) at the sites at or near Jackson Lake Junction (sites 2,4,10,11), and also near the Moran weather station, are analyzed further. A trends Figure (3) shows that Vesper Sparrows were low in density in Y2000, Brewer's, Lincoln's, and Whitecrowned Sparrows were higher in density relative to recent years, and Song, Fox, Savannah Sparrows similar in density.

It appears that a suite of sparrow species is higher in density in certain years, while other species are lower in density. Warmer and especially drier years seems to favor some species, which in turn are favored in cooler and especially wetter years.

Regression analyses were conducted on sparrow densities at the JLJ sites with climatic measures as the independent variables. I used a) summed precipitation in the wettest of the preceding winter months (NOV, DEC, JAN); b) summed precipitation in the months FEB through JUN; and c) summed MAY-JUN monthly average temperatures. Some combination of these independent variables, often just one of them, were significant contributors to sparrow density in most species, and least effective in Song, Fox and Lincoln's Sparrows (see Figure 4). Anomalous years, in which observed and predicted densities are more widely disparate, are noticed in the figure.

\section{The Y2000 Censuses.}


Densities of most species that occur at more than one of the JLJ sites are positively correlated among sites and within years. There are two exceptions: Savannah Sparrow density in site 2 increases in years following heavy winter precipitation, but declines in site 4 in such years, being higher there in years of light winter precipitation. It appears that this sparrow prefers the sedge meadow (2) in wet years, but in dry years the grass-sage site (4) is preferred. Lincoln's Sparrow, which breeds in sites 10 and 11 , is also uncorrelated in density between sites within years. In fact, densities are correlated with $5 / 7$ climatic variables with opposite sign at the two sites. In the Wet Willows site (10) Lincoln's Sparrow density is negatively correlated with all precipitation measures, but in the drier site (Oxbow Willow-Aspen, \#11) positively correlated. It appears that this sparrow avoids the Wet Willows and settles preferentially in the drier Willow-Aspen site in wet years.

The three species with poor correlation with on-site weather variables are those Melospiza sparrows that are short distance or resident species, in contrast with the other sparrows that are longer distance migrants. Song and Fox Sparrow are particularly interesting, as both are usually common in site 10 and there is a mild antagonistic interaction between them over territories. Song Sparrow in usually denser following wet winters and cool springs, while the opposite is true for Lincoln's Sparrow. However, there appears to be a carryover of high density in Song Sparrow in a good Song Sparrow year to a high density the following year, even though the following years may not be a good Song Sparrow year according to local weather conditions. In 1997, for example, local weather predicted a high density of Song Sparrow, $2.04 \mathrm{pr} / \mathrm{ha}$, and a high density was observed (2.14). The following year, 1998, was predicted about average for Song Sparrow density (1.72 pr/ha), but observed density was a high $2.57 \mathrm{pr} / \mathrm{ha}$. It appears that the previous year's successes carried over to the following breeding season in this resident species.

Densities of Song and Lincoln's Sparrow are modestly and negatively correlated at this site. Not all of this negative correlation is due to their opposite responses to local weather. A regression analysis of Lincoln's Sparrow departure from predicted density, $\mathrm{LS}_{\mathrm{dev}}$, against that for Song Sparrow, $\mathrm{SS}_{\mathrm{dev}}$, reveals nothing significant, but a particularly strong negative correlation is apparent when $\mathrm{LS}_{\mathrm{dev}}$ is plotted against $\mathrm{SS}_{\mathrm{dev}}$ for the previous year: $\mathrm{LS}_{\mathrm{dev}}=0.103-$ $0.687 * \mathrm{SS}_{\mathrm{dev}} ; \mathrm{p}=0.008$. It appears that Lincoln's Sparrows are reduced in density when Song Sparrows were especially common the previous year, even though in the (present) year in question conditions may suit Lincoln's rather than Song Sparrows.

With additional years of data, more of these sorts of influences, of local weather on breeding densities and of present and prior densities of one species affecting those of another, will become discernible.

Figure 1.

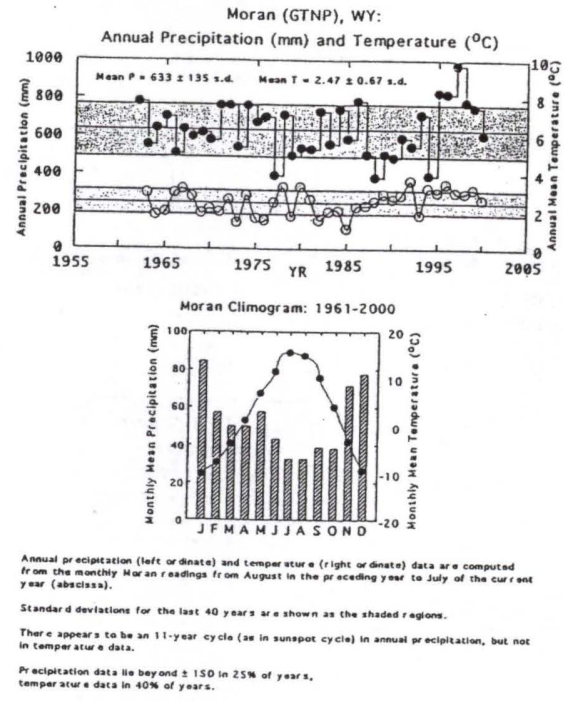

Figure 2a
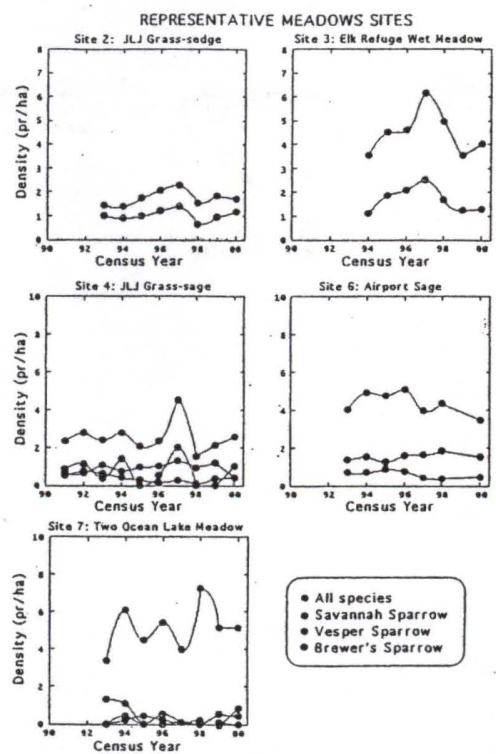

- All species - Savannah Sparro
Vesper Sparrow - Vesper Sparrow 
Figure 2b
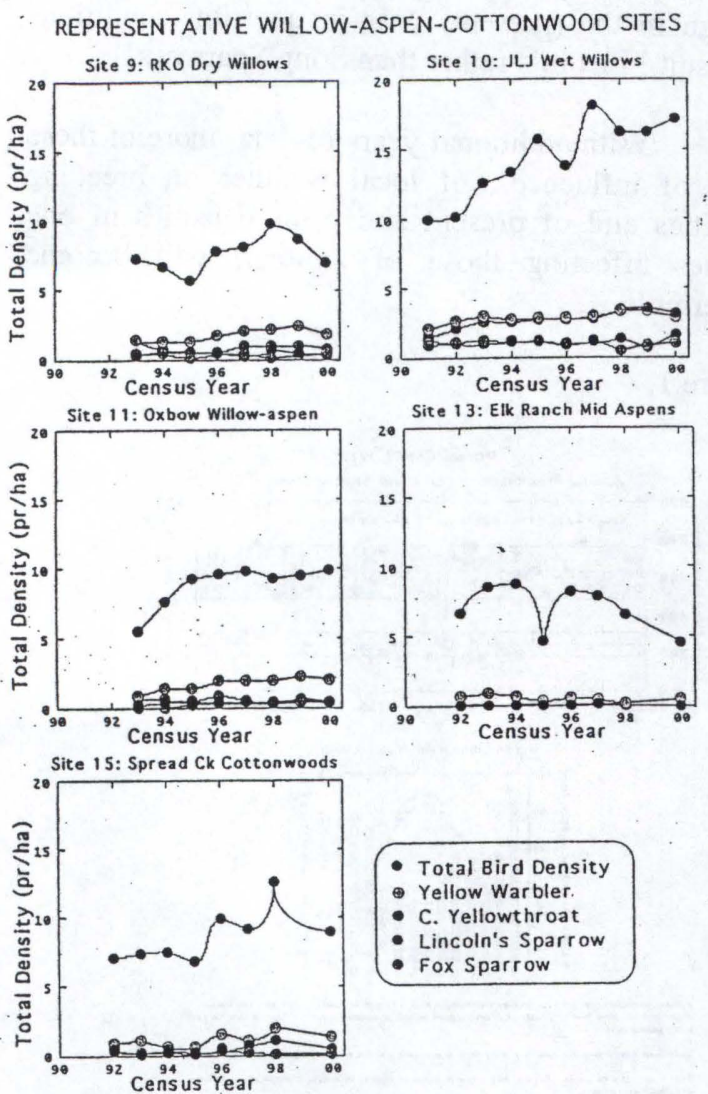

- Total Bird Density

- Yellow Warbler.

- C. Yellowthroat

- Lincoln's Sparrow

- Fox Sparrow

Figure 2c

REPRESENTATIVE PINE-FIR-SPRUCE SITES

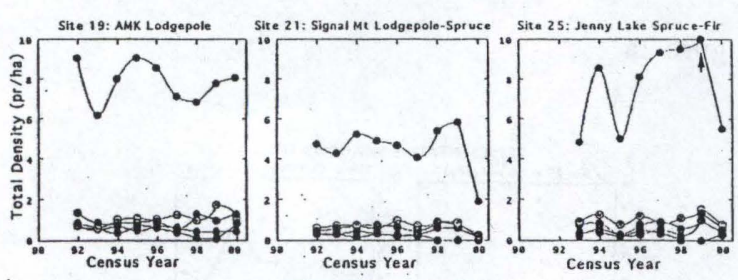

- Total Bird Density - Vellow-rumped Warter - Chippling Sparrow - Ruby-crowned Kinglet
Figure 3

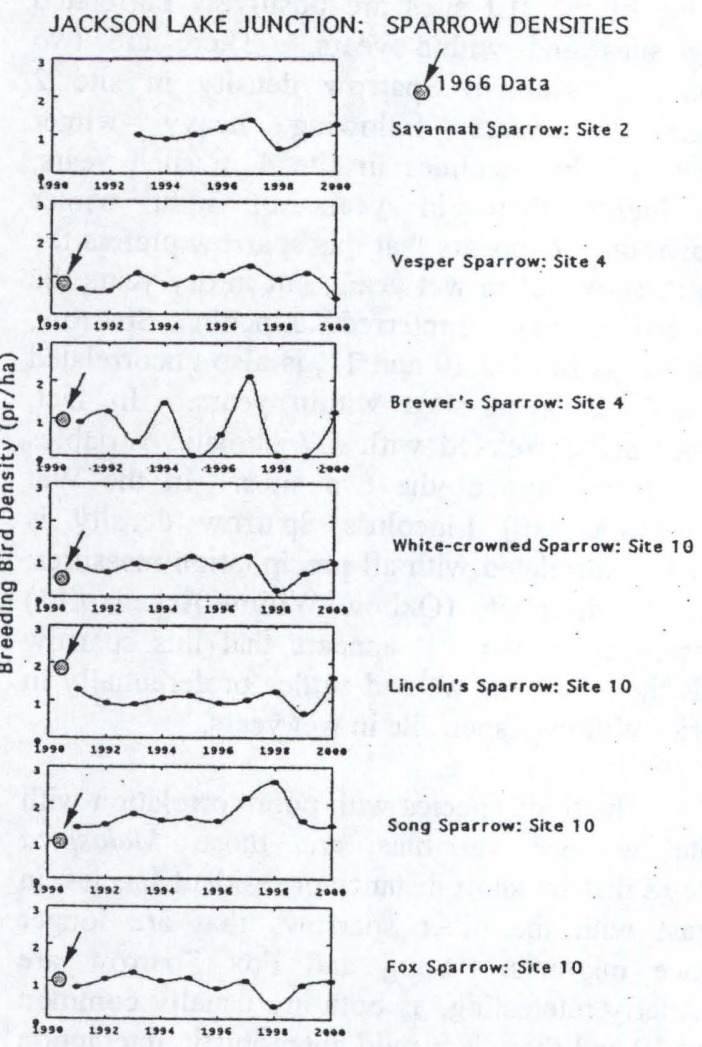

Figure 4

SPARROW DENSITIES ARE RELATED \pm TO LOCAL. WEATHER Savannah Sparrow Brewer's, Vesper Sparrow
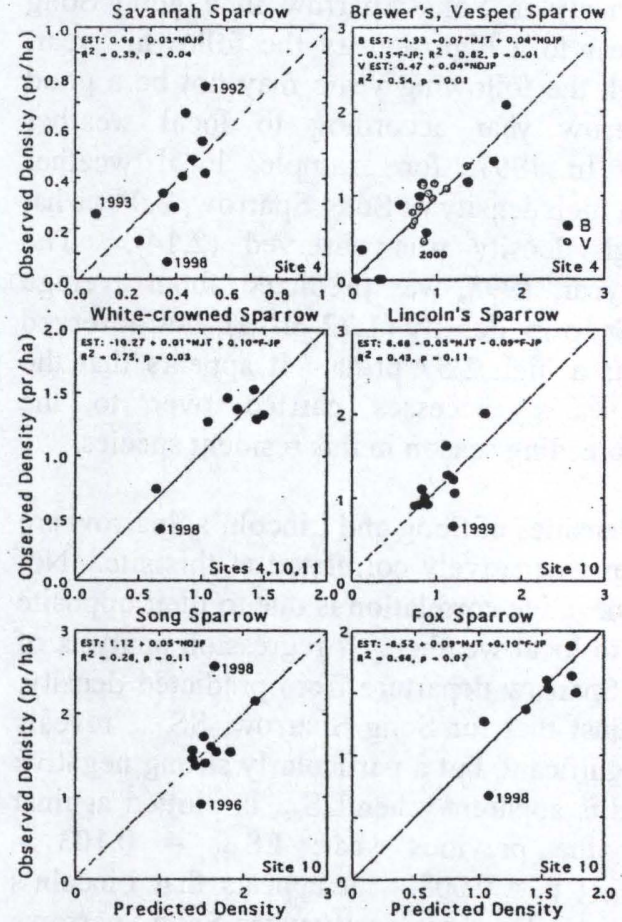
Appendix A

\begin{tabular}{|c|c|c|c|}
\hline GTNP MONIT & ING SITES: SPECIE & $1995-2000$ & \\
\hline PELECANIDAE & White Pelican & Pelecanus erythrorhynchus & \\
\hline ARDEIDAE & Great Blue Heron & Ardea herodias & \\
\hline GRUIDAE & Sandhill Crane & Grus canadensis & \\
\hline & & & \\
\hline ANATIDAE & Trumpeter Swan & Cygnus buccinator & \\
\hline & Canada Goose & Branta canadensis & \\
\hline & Mallard & Anas platyrhynchos & \\
\hline & Gadwall & Anas strepera & \\
\hline & American Wigeon & Anas americana & \\
\hline & Cinnamon Teal & Anas cyanoptera & \\
\hline & Green-winged Teal & Anas crecca & \\
\hline & Blue-winged Teal & Anas discors & \\
\hline & Redhead & Aythya americana & \\
\hline & Ring-necked Duck & Aythya collaris & \\
\hline & Lesser Scaup & Aythya affinis & \\
\hline & Common Merganser & Mergus serrator & \\
\hline & Barrow's Goldeneye & Bucephala islandica & \\
\hline & Common Goldeneye & Bucephala clangula & \\
\hline & Bufflehead & Bucephala albeola & \\
\hline & Wood Duck & Aix sponsa & \\
\hline RALLIDAE & | Virginia Rail & Rallus limicola & \\
\hline & Sora & Porzana carolina & \\
\hline & American Coot & Fulica americana & \\
\hline & & & \\
\hline & Kildeer & Charadrius vociterus & \\
\hline & Willet & Catoptrophorus semipalmatu & \\
\hline SCOLOPACIDAE & Long-billed Curlew & Numenius americanus & \\
\hline & Spotted Sandpiper & Actitis macularia & \\
\hline & Wilson's phalarope & Phlaropus tricolor & \\
\hline & Common Snipe & Gallinago gallinago & \\
\hline LARIDAE & Franklin's Gull & Larus pipixcan & \\
\hline & California Gull & Larus californicus & \\
\hline & Ring-billed gull & Larus delawarensis & \\
\hline CATHARTIDAE & Turkey Vulture & Cathartes aura & \\
\hline ACCIPITRIDAE & Golden Eagle & Aquila chrysaetos & \\
\hline & Bald Eagle & Haliaeetus leucocephalus & \\
\hline & Northern Harrier & Circus cyaneus & \\
\hline & Red-tailed Hawk & Buteo jamaicensis & \\
\hline & Swainson's Hawk & Buteo swainsoni & \\
\hline & Osprey & Pandion haliaetus & \\
\hline
\end{tabular}


Appendix A (continued)

\begin{tabular}{|c|c|c|c|}
\hline & Sharp-shinned Hawk & Accipiter striatus & \\
\hline & Cooper's Hawk & Accipiter cooperi & \\
\hline & Northern Goshawk & Accipiter gentilis & \\
\hline \multirow{2}{*}{ FALCONIDAE } & American Kestrel & Falco tinnunculus & \\
\hline & Prairie Falcon & Falco mexicanus & \\
\hline \multirow[t]{3}{*}{ PHASIANIDAE } & Ruffed Grouse & Bonasa umbellus & \\
\hline & Blue Grouse & Dendrogapus obscurus & \\
\hline & Sage Grouse & Centrocercus urophasianus & \\
\hline \multirow[t]{2}{*}{ COLUMBIDAE } & Mourning Dove & Zeneadura macroura & \\
\hline & Great Grav Owl & Strix nebulosa & \\
\hline \multirow{4}{*}{ STRIGIDAE } & Great Horned Owl & Bubo virginianus & \\
\hline & Long-eared Owl & Asio otus & \\
\hline & Short-eared owl & Asio flammeus & \\
\hline & Northern Pygmy-Owl & Glaucidium gnoma & \\
\hline CAPRIMULGIDAE & Common nighthawk & Phalaenoptilus nuttalli & \\
\hline \multirow[t]{3}{*}{ TROCHILIDAE } & Calliope Hummingbird & Stellula caliope & \\
\hline & Broad-tailed hummingbird & Selasphorus platycercus & \\
\hline & Rufous hummingbird & Selasphorus rufus & \\
\hline ALCENIDAE & Belted Kingfisher & Ceryle alcyon & \\
\hline \multirow[t]{7}{*}{ PICIDAE } & Northern Flicker & Colaptes auratus & \\
\hline & Williamson's Sapsucker & Sphyrapicus thyroides & \\
\hline & Red-naped Sapsucker & Sphyrapicus nuchalis & \\
\hline & Downy Woodpecker & $\begin{array}{l}\text { Picoides pubescens } \\
\end{array}$ & \\
\hline & Hairy Woodpecker & Picoides villosus & \\
\hline & Three-toed Woodpecker & Picoides tridactylus & \\
\hline & Black-backed Woodpecker & Picoides arcticus & \\
\hline \multirow[t]{8}{*}{ TYRANNIDAE } & Western Wood Pewee & Contopus sordidulus & \\
\hline & Olive-sided Flycatcher & Nuttallornis borealis & \\
\hline & Say's Phoebe & Sayornis saya & \\
\hline & Dusky Flycatcher & Empidonax oberholseri & \\
\hline & Hammond's Flycatcher & Empidonax hammondii & \\
\hline & Least Flycatcher & Empidonax traillii & \\
\hline & Willow flycatcher & Empidonax difficilis & \\
\hline & Cordilleran Flycatcher & Empidonax ex. difficilis & \\
\hline \multirow{5}{*}{ HIRUNDINIDAE } & Tree Swallow & Tachycineta bicolor & \\
\hline & Violet-green swallow & Tachycineta thalassina & \\
\hline & Rough-winged Swallow & Stelgidoptery $x$ serripennis & \\
\hline & Cliff Swallow & Hirundo pyrrhonota & \\
\hline & Barn Swallow & Hirundo rustica & \\
\hline
\end{tabular}


Appendix A (continued)

\begin{tabular}{|c|c|c|}
\hline & Bank Swallow & Riparia riparia \\
\hline \multirow[t]{6}{*}{ CORVIDAE } & Steller's Jay & Cyanositta stelleri \\
\hline & Gray Jay & Perisoreus canadensis \\
\hline & Clark's Nutcracker & Nucifraga columniana \\
\hline & Black-billed Magpie & Pica pica \\
\hline & American Crow & Corvus brachyrhynchos \\
\hline & Common Raven & Corvus corax \\
\hline \multirow{2}{*}{ PARIDAE } & Black- capped Chickadee & Parus atricapillus \\
\hline & Mountain Chickadee & Parus gambeli \\
\hline CERTHIDAE & Brown Creeper & Certhia americana \\
\hline \multirow{2}{*}{ SITTIDAE } & White-breasted Nuthatch & Sitta carolinensis \\
\hline & Red-breasted Nuthatch & Sitta canadensis \\
\hline \multirow[t]{3}{*}{ TROGLODYTIDAE } & Marsh Wren & Cistothorus palustris \\
\hline & Rock Wren & Salpinctes obsoletus \\
\hline & House Wren & Troglodytes aedon \\
\hline \multicolumn{3}{|l|}{ MUSCICAPIDAE } \\
\hline \multirow{2}{*}{ Sylviinae } & Golden-crowned Kinglet & Regulus satrapa \\
\hline & $\begin{array}{l}\text { Ruby-crowned Kinglet } \\
\end{array}$ & Regulus calendula \\
\hline \multirow[t]{6}{*}{ Turdinae } & Mountain Bluebird & Sialia currucoides \\
\hline & Townsend's Solitaire & Myadestes townsendi \\
\hline & Veery & Catharus fuscescens \\
\hline & Hermit Thrush & Catharus guttatus \\
\hline & Swainson's Thrush & Catharus ustulatus \\
\hline & American Robin & Turdus migratorius \\
\hline \multirow[t]{2}{*}{ MIMIDAE } & Gray Catbird & Dumatella carolinensis \\
\hline & Sage Thrasher & Oreoscoptes montanus \\
\hline \multirow[t]{2}{*}{ MOTACILLIDAE } & Water Pipit & Anthus spinoletta \\
\hline & & \\
\hline CINCLIDAE & American Dipper & Cinclus mexicanus \\
\hline BOMBYCILLIDAE & Cedar Waxwing & Bombycilla cedrorum \\
\hline \multirow{2}{*}{ STURNIDAE } & European Starling & Sturnùs vulgaris \\
\hline & & \\
\hline \multirow[t]{2}{*}{ VIREONIDAE } & Solitary Vireo & Vireo solitarius \\
\hline & Warbling Vireo & Vireo gilvus \\
\hline PASSERIDAE & House sparrow & Passer domesticus \\
\hline 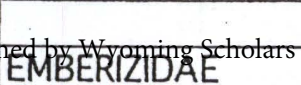 & PDstang 2 -crowned Warbler & Vermivora celata \\
\hline
\end{tabular}

